\title{
Analisis Penilaian Kinerja Pegawai Pada Bagian Kepegawaian dan Umum Direktorat Jenderal P2P Kementerian Kesehatan
}

\author{
Chusminah SM${ }^{1}$, R. Ati Haryati² \\ ${ }^{1}$ Universitas Bina Sarana Informatika/Administrasi Bisnis \\ e-mail: chusminah.csn@bsi.ac.id \\ ${ }^{2}$ Universitas Bina Sarana Informatika/Administrasi Perkantoran \\ e-mail: r.ati.rah@bsi.ac.id
}

Cara Sitasi: Chusminah, \& Haryati, R. A. (2019). Analisis Penilaian Kinerja Pegawai Pada Bagian Kepegawaian dan Umum Direktorat Jenderal P2P Kementerian Kesehatan. Widya Cipta, 3(1), 61-70.

\begin{abstract}
Managing human resources is one of the important elements in any company organization or institute activities. On scope of human resources management there are various human resources activities were an act of taken to provide and maintaining performance adequate for the organization. Through performance assessment be used as a stage of work evaluation that can enhance the quality of employees and produces accurate information behavior and performance of members of the organization. This research is a qualitative descriptive study with method of observation, interviews, and method of documentation. Implementation of performance assessment at Human Resources and General Affair conducted at the end of the year with calculate the element of SKP and work behavior as well as two additional elements, additional duties and creativity. Based on the result of research concerning the performance assessment results period of January-December 2017, for the highest SKP performance assessment is 96 and the lowest is 83 and the highest assessment of work behavior 90 and the lowest 76, the highest average value is 89.84. The method used in performance assessment is rating scale.
\end{abstract}

Keywords: Performance, Appraisal, Employee

\section{PENDAHULUAN}

Mengelola sumber daya manusia merupakan salah satu elemen penting dalam setiap kegiatan organisasi perusahaan ataupun instansi. Artinya sumber daya manusia memiliki peranan penting untuk mewujudkan tujuan perusahaan. Pentingnya peran sumber daya manusia dalam mencapai tujuan perusahaan harus pula diimbangi dengan kemampuan yang dimiliki oleh sumber daya manusianya dan harus benar-benar teruji sehingga mampu mengerjakan semua pekerjaan yang dibebankan kepadanya secara benar dan menghasilkan hasil yang sempurna, baik kuantitas maupun kualitas.

Pada hakikatnya, manajemen sumber daya manusia merupakan gerakan pengakuan terhadap pentingnya unsur manusia sebagai sumber daya yang cukup potensial dan sangat dominan pada setiap organisasi. Dalam ruang lingkup manajemen sumber daya manusia terdapat berbagai aktivitas sumber daya manusia (SDM) yang merupakan tindakan yang diambil untuk memberikan dan mempertahankan kinerja yang memadai bagi organisasi. Salah satu aktivitas sumber daya manusia yaitu penilaian kinerja.
Kinerja menggambarkan sejauh mana aktivitas seseorang dalam melaksanakan tugas dan berusaha dalam mencapai tujuan yang ditetapkan. Tingkat kinerja pegawai sangat tergantung pada dua faktor, yaitu kemampuan pegawai dan motivasi kerja. Kemampuan pegawai seperti tingkat pendidikan, pengetahuan, dan pengalaman. Manajemen kinerja dapat memberikan keuntungan kepada berbagai pihak, baik pimpinan, pegawai, maupun organisasi. Manajemen kinerja memerlukan kegiatan penilaian kinerja secara objektif dan berkala karena dapat memberikan informasi mengenai produktivitas pegawai.

Penilaian kinerja merupakan tahap evaluasi kerja yang dapat meningkatkan kualitas pegawai bagi kelangsungan aktivitas perusahaan didalamnya. Penilaian kinerja dilakukan meliputi hasil kerja, jangka waktu serta perilaku pegawai. Penilaian kinerja meliputi beberapa hal, sesuai yang telah ditetapkan perusahaannya. Tujuan pokok sistem penilaian kinerja adalah menghasilkan informasi yang akurat tentang perilaku dan kinerja anggotaanggota organisasi. Informasi penilaian kinerja memberikan juga dasar bagi perencananaan, pelatihan, dan pengembangan.

Penilaian kinerja diartikan pula sebagai mekanisme 
yang baik untuk mengendalikan pegawai, membuat keputusan-keputusan yang berkaitan dengan kenaikan gaji, pemberian bonus, dan promosi. Untuk itu, metode penilaian kinerja menjadi penting untuk diperhatikan, mengingat bagus tidaknya penilaian kinerja yang dilakukan akan dipengaruhi oleh tepat tidaknya metode penilaian yang dipilih dan diimplementasikan.

Penelitian ini bertujuan untuk menganalisis penerapan penilaian kinerja pegawai yang dilakukan di Bagian Kepegawaian dan Umum pada Direktorat Jenderal P2P Kementerian Kesehatan RI yang berlokasi di Jakarta.

\section{Penilaian Kinerja}

Kinerja merupakan hasil kerja yang dapat dicapai oleh seseorang atau sekelompok orang dalam suatu organisasi, sesuai dengan wewenang dan tanggung jawab masing-masing dalam rangka mencapai tujuan organisasi menurut Prawirosentono dalam (Sinambela, 2016).

Menurut Mathis dan Jackson dalam (Tangkuman, Tewal, \& Trang, 2015) penilaian kinerja (performance appraisal) adalah "proses mengevaluasi seberapa baik karyawan melakukan pekerjaan mereka jika dibandingkan dengan seperangkat standar, dan kemudian mengkomunikasikan informasi tersebut pada karyawan".

Bernardin dan Russel yang dikutip oleh Ruky dalam Zainal (2015:406) "performance is defined as the record of outcomes produced on a specified job function or activity during time period".

Menurut Werner dalam (Erwin \& Prabowo, 2015) menyimpulkan bahwa penilaian kinerja sangat dibutuhkan dalam mengevaluasi suatu perusahaan agar organisasi sukses, penting bahwa manajer menetapkan tujuan yang jelas secara keseluruhan, nilai-nilai inti, visi masa depan, dan juga mengembangkan strategi yang bisa diterapkan untuk mencapai hal-hal ini

Menurut Sedarmayanti dalam (Ainnisya \& Susilowati, 2018) bahwa banyak manfaat yang didapat dari penilaian kinerja, yaitu:

1. Meningkatkan prestasi kerja. Dengan adanya penilaian, baik pimpinan atau karyawan memperoleh umpan balik dan mereka dapat memperbaiki pekerjaannya atau prestasinya.

2. Memberi kesempatan kerja adil. Penilaian akurat dapat menjamin karyawan memperoleh kesempatan menempati posisi pekerjaan sesuai kemampuannya

3. Kebutuhan pelatihan dan pengembangan. Melalui penilaian kinerja, terdeteksi karyawan yang kemampuannya rendah sehingga memungkinkan adanya program pelatihan untuk meningkatkan kemampuan mereka.

4. Penyesuaian kompensasi.

5. Keputusan promosi dan demosi.

6. Mendiagnosis kesalahan desain pekerjaan. Kinerja yang buruk mungkin suatu tanda kesalahan dalam desain pekerjaan.

7. Menilai proses rekrutmen dan seleksi.

Menurut Zainal (2015:408) tujuan penilaian kinerja atau prestasi kinerja karyawan pada dasarnya meliputi:

1. Untuk mengetahui tingkat prestasi karyawan selama ini

2. Pemberian imbalan yang serasi, misalnya untuk pemberian kenaikan gaji berkala, gaji pokok, dan insentif.

3. Pengembangan SDM yang masih dapat dibedakan lagi ke dalam:

a. Penugasan kembali, seperti diadakannya mutasi atau transfer, rotasi pekerjaan

b. Promosi, kenaikan jabatan.

c. Training atau latihan.

4. Meningkatkan motivasi kerja dan etos kerja

5. Sebagai salah satu sumber informasi untuk perencanaan SDM, karir dan keputusan perencanaan sukses

6. Sebagai alat untuk menjaga tingkat kinerja serta membantu dan mendorong karyawan untuk mengambil inisiatif dalam rangka memperbaiki kinerja.

Menurut Sutrisno (2016:186-187) ada beberapa proses penilaian kinerja dilakukan melalui:

1. Menyusun rencana kerja

Rencana kerja merupakan tahap dalam menyepakati sasaran kerja yang harus dicapai dan juga sikap serta perilaku yang mesti ditampilkan pegawai dalam satu periode penilaian ke depan.

2. Pelaksanaan

Pelaksanaan merupakan pengerjaan atas rencana yang dilaksanakan oleh pegawai dengan sebaikbaiknya, sesuai dengan yang telah direncanakan sebelumnya.

3. Pembinaan

Pembinaan merupakan tahap untuk memantau pencapaian sasaran kerja selama periode penilaian.

4. Pengawasan atau peninjauan

Peninjauan merupakan tahap untuk mengukur pencapaian sasaran dan perilaku kerja bawahan, serta menarik kesimpulan tentang apa yang telah berjalan dengan efektif dan yang belum efektif dari sebelumnya.

5. Mengendalikan

Kegiatan pengendalian dilakukan jika dalam pelaksanaan terjadi penyimpangan atas pelaksanaan yang dilakukan 
Berdasarkan pendapat beberapa ahli yang dikutip dalam jurnalnya (Januari, Utami, \& Ruhana, 2015), bahwa terdapat faktor-faktor yang mempengaruhi proses penilaian kinerja, yaitu:

1. Indikator penilaian kinerja

Kriteria kinerja menurut Schuker dan Jackson dalam Mulyana adalah, kriteria berdasarkan sifat, kriteria berdasarkan perilaku, dan kriteria berdasarkan hasil.

2. Metode penilaian kinerja

Menurut Casio dalam Soeprihanto metode penilaian kinerja harus mencakup lima hal, yaitu relevance (kesesuaian hasil dan tujuan), acceptability (dapat diterima), reliability (dapat dipercaya), sensitivity (dapat membedakan hasil kerja), dan practically (meningkatkan produktivitas).

3. Penilai

Menurut Hasibuan penetapan penilaian sangat erat hubungannya dengan persoalan apakah hasil penilaian obyektif atau tidak.

4. Pelaksanaan penilaian kinerja

Hasibuan berpendapat bahwa pelaksanaan penilaian kinerja harus mencakup dua hal, yaitu: waktu pelaksanaan dan konteks penilaian.

\section{Prinsip Penilaian Kinerja}

Menurut (Sari, Setiawan, \& Adilah, 2017) terdapat beberapa prinsip pengukuran kinerja yakni:

1. Seluruh aktivitas kerja yang signifikan harus diukur

2. Pekerjaan yang tidak dapat diukur atau dinilai tidak dapat dikelola karena darinya tidak ada informasi yang bersifat obyektif untuk menentukan nilainya.

3. Kerja yang tak diukur selayaknya diminimalisir atau bahkan ditiadakan.

4. Keluaran kinerja yang diharapkan harus ditetapkan untuk seluruh kerja yang diukur

5. Hasil keluaran menyediakan dasar untuk menetapkan akuntabilitas hasil alih-alih sekedar mengetahui tingkat usaha

6. Mendefinisikan kinerja dalam artian hasil kerja semacam apa yang diinginkan adalah cara manajer dan pengawas untuk membuat penugasan kerja dari mereka menjadi operasional

7. Pelaporan kinerja dan analisis variansi harus dilakukan secara kerap

8. Pelaporan kerap memungkinkan adanya tindakan korektif yang segera dan tepat waktu

9. Tindakan korektif yang tepat waktu begitu dibutuhkan untuk manajemen kendali yang efektif

Menurut Sutrisno (2016:201-202) agar memperoleh hasil kinerja seperti yang diinginkan, maka penilaian kinerja harus dilakukan sesuai dengan asas-asas penilaian kinerja. Jika melanggar dari asas-asas tersebut, maka dapat dipastikan bahwa hasil penilaiannya tidak akan berjalan baik, termasuk hasil penilaian kinerjanya. Artinya asas-asas penilaian kinerja harus dijalankan secara benar dan konsisten, sehingga hasil yang diharapkan dapat dipertanggungjawabkan.

Dalam praktiknya asas-asas penilaian untuk melakukan penilaian kinerja harus dilakukan:

1. Secara objektif

Objektif artinya melakukan penilaian harus dilakukan apa adanya sesuai dengan kriteria yang telah ditetapkan. Artinya penilai dalam menilai jangan terpengaruh oleh hal-hal di luar yang telah ditentukan. Untuk melakukan penilaian yang dilakukan secara objektif biasanya dilakukan secara:

a. Realistis, artinya menilai apa adanya sesuai dengan yang telah dilakukan

b. Terukur, artinya setiap pekerjaan dapat menggunakan standar tertentu sebagai alat ukur pencapaian kinerjanya.

c. Menantang, artinya pekerjaan yang diberikan dapat memberikan motivasi bagi karyawan untuk mengerjakan.

d. Berdasarkan skala prioritas, artinya dalam mengerjakan suatu pekerjaan dibuatkan lebih dulu mana yang harus dikerjakan yang pertama dan yang selanjutnya.

2. Secara adil

Adil artinya dalam menilai harus memberikan kesempatan yang sama kepada setiap karyawan. Memberikan peluang yang sama untuk dinilai sehingga tidak menimbulkan kecemburuan di antara karyawan.

Adapun keadilan dapat dilakukan berdasarkan:

a. Pembagian tugas disesuaikan dengan posisi dan kompetensi yang dimiliki

b. Penilaian disesuaikan dengan kontribusi karyawan terhadap keberhasilan unit kerja atau organisasi.

c. Penilaian dilakukan secara objektif dengan didukung data dan informasi yang ada

d. Pemberian balas jasa didasarkan kepada kontribusi dan kompetensi yang berlaku.

3. Secara transparan

Disamping objektif dan adil dalam melaksanakan penilaian, juga perlu diperhatikan adalah faktor transparansi. Artinya dalam melakukan penilaian harus dengan adanya keterbukaan, baik dalam proses menilai serta memberikan hasil penilaian. Transparan dalam melakukan penilaian kinerja karyawan artinya dalam hal:

a. Adanya parameter untuk mengukur kinerja serta sumber data yang digunakan

b. Mengumumkan hasil penilaian secara terbuka, jangan sampai ada yang disembunyikan

c. Pemberian balas jasa atas kinerja yang dihasilkan harus jelas, sehingga tidak menimbulkan kecurigaan

Menurut Kasmir dalam (Ainnisya \& Susilowati, 2018) penilaian kinerja dilakukan dengan melalui 
beberapa komponen penilaian kinerja. Untuk memudahkan pemahaman komponen penilaian yang umum diberikan sebagai berikut:

1. Absensi

Absensi merupakan keberadaan atau bukti kehadiran karyawan pada saat masuk kerja sampai dengan pulang kerja.

2. Kejujuran

Kejujuran merupakan perilaku karyawan selama berkerja dalam suatu periode. Nilai kejujuran seorang karyawan biasanya dinilai berdasarkan ukuran yang telah ditetapkan sebelumnya.

3. Tanggung jawab

Karyawan bertanggung jawab atas pekerjaan yang dilakukannya. Tanggung jawab tersebut dapat berupa kerugian langsung akibat dari perbuatannya atau kerugian tidak langsung.

4. Kemampuan (hasil kerja)

Penilaian terhadap kemampuan karyawan biasanya didasarkan kepada waktu untuk mengerjakan, jumlah pekerjaan dan kualitas pekerjaan itu sendiri.

5. Loyalitas

Loyalitas merupakan kesetiaan seseorang karyawan terhadap perusahaan. Seorang karyawan harus setia membela kepentingan perusahaan.

6. Kepatuhan

Merupakan suatu ketaatan karyawan dalam mengikuti seluruh kebijakan atau peraturan perusahaan dan ketaatan untuk tidak melanggar yang sudah diperintahkan.

7. Kerjasama

Saling membantu diantara karyawan baik antar bagian atau bagian lain bertujuan untuk mempercepat atau memperlancar kegiatan.

8. Kepemimpinan

Kepemimpinan artinya yang dinilai adalah kemampuan seseorang dalam memimpin.

9. Prakarsa

Merupakan seseorang yang selalu memiliki ide-ide atau pendapat perbaikan atau pengembangan atas kualitas suatu pekerjaan.

Menurut Zainal (2015:416-427) bahwa metode atau teknik penilaian kinerja karyawan dapat digunakan dengan pendekatan yang berorientasi masa lalu dan masa depan. Dalam praktiknya tidak ada satupun teknik yang sempurna. Pasti ada saja keunggulan dan kelemahannya.

1. Metode Penilaian Berorientasi Masa Lalu

Ada beberapa metode untuk menilai kinerja diwaktu yang lalu. Teknik-teknik penilaian ini meliputi:

a. Skala Peringkat (Rating Scale)

Merupakan metode yang paling banyak digunakan dalam penilaian kinerja, dimana para penilai diharuskan melakukan suatu penilaian yang berhubungan dengan hasil kerja karyawan dalam skala-skala tertentu, mulai dari yang paling rendah sampai yang paling tinggi. Penilaian didasarkan pada pendapat para penilai. Pada umumnya penilai diberi formulir, yang berisi sejumlah sifat dan ciriciri hasil kerja yang harus diisi. Penilaian pada umumnya diisi oleh atasan yang memutuskan pendapat apa yang paling sesuai untuk setiap tingkatan hasil kerja.

b. Daftar Pertanyaan (Checklist)

Penilaian berdasarkan metode ini terdiri dari sejumlah pertanyaan yang menjelaskan beraneka macam tingkat perilaku bagi suatu pekerjaan tertentu. Penilai tinggal memilih kata atau pernyataan yang menggambarkan karakteristik dan hasil kerja karyawan. Selain itu, sebagai penilai biasanya atasan langsung.

c. Tes dan Observasi Prestasi Kerja

Metode ini didasarkan pada tes pengetahuan dan keterampilan, berupa tes tertulis dan peragaan.

d. Pendekatan Evaluasi Komparatif

Metode ini mengutamakan perbandingan prestasi kerja seseorang dengan karyawan lain yang menyelenggarakan kegiatan sejenis. Dua metode yang biasa digunakan dari sekian banyak metode dalam penerapan pendekatan komparatif sebagai berikut:

1) Metode Peringkat

Metode ini berarti seorang atau beberapa penilai menentukan peringkat bagi sejumlah karyawan, mulai dari yang paling berprestasi hingga kepada yang paling tidak berprestasi.

2) Distribusi Terkendali

Suatu metode penilaian dimana penilai menggolongkan karyawan yang dinilai ke dalam klasifikasi yang berbeda-beda berdasarkan berbagai faktor kritikal yang berlainan seperti prestasi kerja, ketaatan, disiplin, dan lain sebagainya.

2. Metode Penilaian Berorientasi Masa Depan

Metode penilaian berorientasi masa depan menggunakan asumsi bahwa karyawan tidak lagi sebagai objek penilaian yang tunduk dan tergantung pada penyelia, tetapi karyawan dilibatkan dalam proses penilaian. Teknik-teknik ini meliputi:

a. Penilaian Diri Sendiri (Self Appraisal)

Penilaian diri sendiri adalah penilaian yang dilakukan oleh karyawan sendiri dengan harapan karyawan tersebut dapat lebih mengenal kekuatan-kekuatan dan kelemahannya sehingga mampu mengidentifikasikan aspek-aspek perilaku kerja yang perlu diperbaiki pada masa yang akan datang. Salah satu kebaikan dari metode ini adalah dapat mencegah terjadinya perilaku membenarkan diri (defensive behavior).
b. Manajemen Berdasarkan Sasaran (Management By Objective) 
Management by objective (MBO) yang berarti manajemen berdasarkan sasaran, artinya adalah satu bentuk penilaian dimana karyawan dan penyelia bersama-sama menetapkan tujuan-tujuan atau sasaran-sasaran pelaksanaan kerja di waktu yang akan datang. Pemakaian metode ini terutama ditujukan untuk keperluan pengembangan karyawan. Metode ini lebih mengacu pada pendekatan hasil.

c. Penilaian Secara Psikologis

Penilaian secara psikologis adalah proses penilaian yang dilakukan oleh para ahli psikologi untuk mengetahui potensi seseorang yang berkaitan dengan pelaksanaan pekerjaan seperti kemampuan intelektual, motivasi, dan lain-lain yang bersifat psikologis.

\section{Kesalahan dalam Penilaian Kinerja}

Menurut Sutrisno (2016:210-212) dalam praktiknya penilaian kinerja memliki banyak kelemahan, sekalipun telah dilakukan dengan benar. Berikut ini beberapa kesalahan yang sering terjadi dalam penilaian kinerja yaitu:

1. Kesamaan dengan penilai

Dalam hal ini penilai memberikan nilai yang memiliki efek kesamaan tertentu dengan si penilai. Biasanya kesamaan dapat berupa asalusul, alumni, suku, ras, agama, domisili, dan kesamaan lainnya.

2. Bias

Bias merupakan kepribadian seseorang yang dalam memberikan nilai yang biasa dengan nilai terlalu lunak (leniency bias), atau sebaliknya pemberian nilai terlalu ketat (strickness bias).

3. Hallo effect

Hallo effect merupakan penilaian kepada seseorang yang didasarkan pada perasaan sipenilai. Artinya, jika perasaan lagi senang, maka nilainya baik, namun jika perasaannya kurang senang maka penilaiannya menjadi sebaliknya.

4. Hubungan jabatan

Artinya penilaian dilakukan dengan hubungan jabatan tertentu. Seorang penilai yang memiliki hubungan dengan suatu jabatan tertentu akan menilai dengan baik, demikian pula sebaliknya.

5. Penilaian rata-rata

Yaitu penilai dalam melakukan penilaian yang cenderung memberi nilai rata-rata. Orang seperti ini cenderung berprasangka pribadi. Artinya penilaian kepada seseorang cenderung kepada sesuatu yang dianggapnya benar.

\section{METODOLOGI PENELITIAN}

Penelitian ini menggunakan pendekatan deskriptif kualitatif. Peneliti kualitatif menekankan sifat realitas yang dikonstruksi secara sosial, hubungan intim antara peneliti dan apa yang dipelajari, dan kendala situasional yang membentuk penyelidikan. Peneliti semacam itu menekankan sifat penyelidikan yang sarat nilai. Dalam penelitian ini peneliti mencocokkan antara realita empiris yang dilakukan saat penilaian kinerja di Bagian Kepegawaian dan Umum Dirjen P2P Kementerian Kesehatan RI dengan teori yang berlaku dalam ranah akademik. Metode pengumpulan data yang peneliti gunakan meliputi:

1. Observasi

Observasi merupakan pengamatan langsung pada obyek penelitian. Tujuan menggunakan metode ini untuk mencatat hal-hal, perilaku, perkembangan, dan sebagainya tentang penerapan penilaian kinerja di Bagian Kepegawaian dan Umum Dirjen P2P Kementerian Kesehatan RI.

2. Wawancara

Wawancara mendalam sangat optimal untuk mengumpulkan data tentang sejarah perusahaan atau organisasi, pengalaman dan praktek terbaik perusahaan terutama ketika topik-topik sensitif sedang dieksplorasi. Hasil wawancara sebagai sumber data primer yang digunakan untuk menjawab permasalahan dalam penelitian ini. Pertanyaan diajukan kepada Kepala Subbagian Kepegawaian dan Umum Dirjen P2P Kementerian Kesehatan RI.

3. Studi Pustaka

Merupakan salah satu metode pengumpulan data dari arsip, dokumen, peraturan perundangan, buku, jurnal dan sumber referensi lainnya yang mendukung penelitian ini.

\section{HASIL DAN PEMBAHASAN}

Pegawai negeri sipil (PNS) merupakan pegawai yang bekerja dalam lingkungan pemerintahan, di lingkungan kementerian maupun pemerintah daerah. Pegawai negeri sipil merupakan abdi negara yang menjalankan roda pemerintahan, sehingga perlu adanya penilaian kinerja. Penilaian kinerja pegawai dilakukan untuk mengevaluasi pelaksanaan kinerja dengan cara membandingkan antara rencana kerja dan hasil kerjanya.

Dalam pelaksanaan penilaian kinerja pegawai negeri sipil diatur dalam peraturan perundang-undangan pemerintah yang berlaku untuk seluruh pegawai negeri sipil di seluruh Indonesia. Berikut ini beberapa peraturan mengenai penilaian kinerja pegawai negeri sipil yang diterapkan juga oleh Bagian Kepegawaian dan Umum Direktorat Jenderal Pencegahan dan pengendalian Penyakit (P2P) Kementerian Kesehatan:

1. Peraturan Pemerintah Nomor 46 Tahun 2011 tentang Penilaian Prestasi Kerja Pegawai Negeri Sipil

2. Peraturan Kepala Badan Kepegawaian Negara Nomor 1 tahun 2013 tentang Ketentuan Pelaksanaan Peraturan Pemerintah Nomor 46 
Tahun 2011 tentang Penilaian Prestasi Kerja Pegawai Negeri Sipil.

Dalam melakukan penilaian kinerja, peran sebagai penilai sangatlah penting karena tanpa adanya penilai, penilaian kinerja tidak akan berjalan secara efesien. Penilaian kinerja pada Bagian Kepegawaian dan Umum Direktorat Jenderal Pencegahan dan Pengendalian Penyakit (P2P) Kementerian Kesehatan dilakukan oleh pejabat penilai yang berwenang dan atasan pejabat penilai. Pejabat penilai yang melakukan penilaian antara lain yang paling rendah golongan Eselon IV dan yang paling tinggi golongan Eselon I. Setiap pejabat penilai wajib melaksanakan penilaian kinerja dilingkungan unit kerjanya.

Berdasarkan peraturan pemerintah nomor 46 tahun 2011 tentang penilaian prestasi kerja pegawai negeri sipil terdapat dua unsur yang menjadi bahan penilaian kinerja, yaitu:

1. Sasaran Kerja Pegawai (SKP)

Sasaran kerja pegawai (SKP) merupakan kontrak kerja yang harus disusun oleh pegawai pada awal tahun. bobot penilaian untuk sasaran kerja pegawai sebesar $60 \%$. Dalam penyusunan sasaran kerja pegawai terdapat unsur-unsur yang harus dipenuhi, yaitu:

a. Kegiatan tugas jabatan

Setiap kegiatan tugas jabatan yang akan dilakukan harus didasarkan pada uraian tugas, tanggung jawab dan wewenang yang secara umum telah ditetapkan dalam struktur organisasi dan tata kerja.

b. Angka kredit

Satuan nilai dari tiap butir kegiatan yang harus dicapai oleh pejabat fungsional dalam rangka pembinaan karier yang bersangkutan ditetapkan dengan jumlah angka kredit yang akan dicapai.

Contoh:

Seorang pegawai negeri sipil dengan jabatan analis kepegawaian didalam sasaran kerja pegawai (SKP) terdapat kegiatan tugas jabatan yang dilaksanakan dan angka kreditnya seperti membuat konsep surat pengantar permintaan pertimbangan pengangkatan dalam jabatan fungsional (0.003/surat) serta membuat konsep surat ijin / keterangan belajar (0.005/surat). Untuk memperoleh angka kredit dengan cara mengalikan satuan angka kredit dengan target kuantitas (output). Misalnya $0.003 \times 100=0.3$.

c. Target

Rencana capaian kegiatan dari tugas jabatan yang akan diwujudkan secara jelas sebagai ukuran prestasi kerja. Dalam menetapkan target meliputi aspek sebagai berikut:

1) Kuantitas (target output)

2) Kualitas (target kualitas)
3) Waktu (target waktu)

4) Biaya

Contoh: Pada sasaran kerja pegawai dengan jabatan pengolah data terdapat beberapa kegiatan tugas pokok jabatan seperti mengelola ISO cuti yang memiliki target kuantitas 1 laporan, kualitas 100, dan waktu 12 bulan serta melakukan verifikasi dan validasi kenaikan pangkat yang memiliki target kuantitas 200 data, kualitas 100, dan waktu 12 bulan.

\section{Perilaku Kerja}

Penilaian perilaku kerja memiliki bobot sebesar $40 \%$. Penilaian perilaku kerja meliputi aspek:

a. Orientasi pelayanan

Sikap dan perilaku pegawai dalam memberikan pelayanan terbaik kepada yang dilayani antara lain meliputi masyarakat, atasan, rekan sekerja, unit kerja terkait, atau instansi lain.

b. Integritas

Kemampuan pegawai untuk bertindak sesuai dengan nilai, norma dan etika dalam berorganisasi.

c. Komitmen

Kemauan dan kemampuan untuk menyelaraskan sikap dan tindakan pegawai untuk mewujudkan tujuan organisasi dengan mengutamakan kepentingan dinas daripada kepentingan diri sendiri, seseorang, atau golongan.

d. Disiplin

Kesanggupan pegawai untuk menaati kewajiban dan menghindari larangan yang ditentukan dalam peraturan perundangundangan atau peraturan kedinasan yang apabila tidak ditaati atau dilanggar dijatuhi hukuman disiplin.

e. Kerjasama

Kemauan dan kemampuan pegawai untuk bekerja sama dengan rekan sekerjanya, atasan, bawahan dalam unit kerjanya serta instansi lain dalam menyelesaikan suatu tugas dan tanggung jawab yang ditentukan, sehingga mencapai daya guna dan hasil guna yang sebesar-besarnya.

f. Kepemimpinan

Kemampuan pegawai untuk memotivasi dan mempengaruhi bawahan atau orang lain yang berkaitan dengan bidang tugasnya demi tercapainya tujuan organisasi.

Selain 2 unsur diatas, terdapat dua unsur penunjang lain yang dapat dijadikan penilaian yaitu penilaian tugas tambahan dan penilaian kreativitas. Bagi pegawai yang melaksanakan tugas yang diberikan oleh atasan langsungnya akan diberikan nilai tugas tambahan paling rendah 1(satu) dan paling tinggi 3 
(tiga) dengan ketentuan sebagai berikut:

Tabel 1. Pedoman Nilai Tambahan

\begin{tabular}{clc}
\hline No & \multicolumn{1}{c}{ Tugas Tambahan } & Nilai \\
\hline 1 & $\begin{array}{l}\text { Tugas tambahan yang dilakukan } \\
\text { dalam 1 (satu) tahun sebanyak 1 } \\
\text { (satu) sampai 3 (tiga) kegiatan }\end{array}$ & 1 \\
\hline 2 & $\begin{array}{l}\text { Tugas tambahan yang dilakukan } \\
\text { dalam 1 (satu) tahun sebanyak 4 } \\
\text { (empat) sampai 6 (enam) }\end{array}$ & \\
& kegiatan & \\
\hline 3 & $\begin{array}{l}\text { Tugas tambahan yang dilakukan } \\
\text { dalam 1 (satu) tahun sebanyak 7 } \\
\text { (tujuh) kegiatan atau lebih }\end{array}$ & \\
\hline Sumber: Bagian Kepegawaian dan Umum Direktorat Jenderal \\
P2P Kementerian Kesehatan
\end{tabular}

Untuk unsur penilaian kreativitas, apabila pegawai menemukan sesuatu yang baru dan berkaitan dengan tugas pokoknya serta dibuktikan dengan surat keterangan dari unit kerja setingkat Eselon II, Pejabat Pembina Kepegawaian atau Presiden. Maka pada akhir tahun yang bersangkutan berhak mendapatkan nilai kreativitas paling rendah 3 (tiga) dan paling tinggi 12 (dua belas) dengan ketentuan sebagai berikut:

Tabel 2. Pedoman Nilai Kreativitas

\begin{tabular}{|c|c|c|}
\hline No & Kreativitas & Nilai \\
\hline 1 & $\begin{array}{l}\text { Apabila hasil yang ditemukan } \\
\text { merupakan sesuatu yang baru dan } \\
\text { bermanfaat bagi unit kerjanya dan } \\
\text { dibuktikan dengan surat keterangan } \\
\text { yang ditandatangani oleh kepala unit } \\
\text { kerja setingkat eselon II. }\end{array}$ & 3 \\
\hline 2 & $\begin{array}{l}\text { Apabila hasil yang ditemukan } \\
\text { merupakan sesuatu yang baru dan } \\
\text { bermanfaat bagi organisasinya serta } \\
\text { dibuktikan dengan surat keterangan } \\
\text { yang ditandatangani oleh Pejabat } \\
\text { Pembina Kepegawaian (PPK) }\end{array}$ & 6 \\
\hline 3 & $\begin{array}{l}\text { Apabila hasil yang ditemukan } \\
\text { merupakan sesuatu yang baru dan } \\
\text { bermanfaat bagi negara dengan } \\
\text { penghargaan yang diberikan oleh } \\
\text { Presiden }\end{array}$ & 12 \\
\hline
\end{tabular}

Berikut ini proses penilaian kinerja pada Bagian Kepegawaian dan Umum Direktorat Jenderal P2P Kementerian Kesehatan:

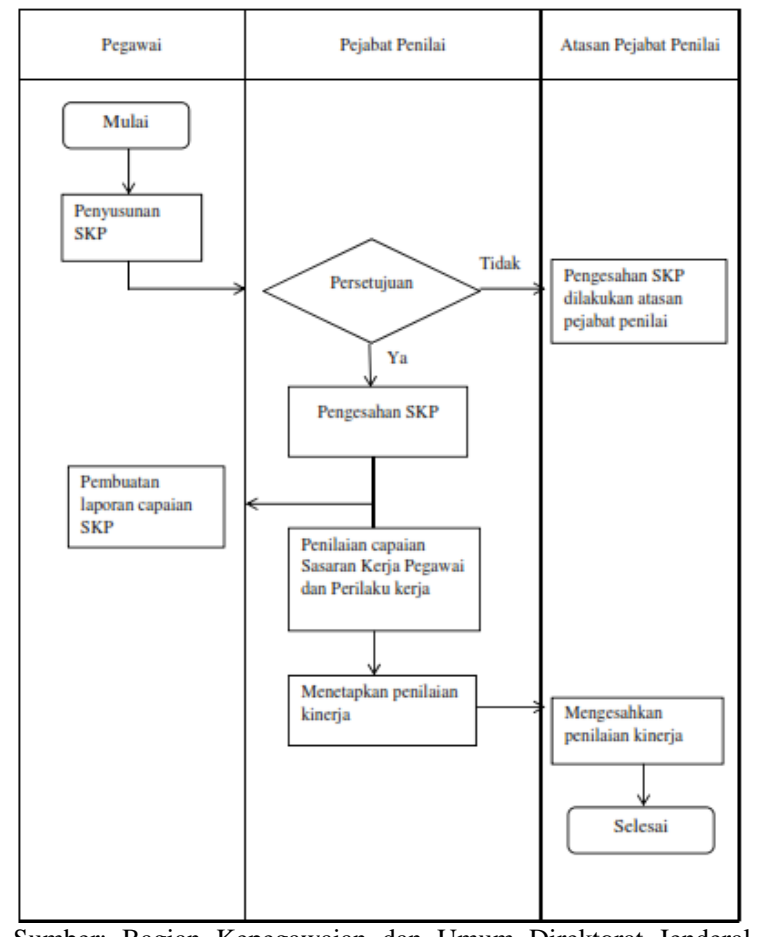

Sumber: Bagian Kepegawaian dan Umum Direktorat Jenderal P2P Kementerian Kesehatan (2017)

Gambar 1. Proses Penilaian Kinerja Bagian Kepegawaian \& Umum P2P Kemenkes

Keterangan gambar 1 di atas, adalah:

1. Pada awal tahun pegawai diwajibkan untuk menyusun sasaran kerja pegawai (SKP) . Sasaran kerja pegawai memuat kegiatan tugas jabatan dan target yang harus dicapai dalam kurun waktu setahun.

2. Setelah penyusunan, pegawai akan meminta tanda tangan atau persetujuan dari pejabat penilai sebagai kontrak kerja. Apabila sasaran kerja pegawai tidak disetujui oleh pejabat penilai, maka keputusannya diserahkan kepada atasan pejabat penilai.

3. Setelah pejabat penilai mengesahkan sasaran kerja pegawai, formulir penyusunan sasaran kerja pegawai akan dikembalikan kepada pegawai sebagai kontrak kerja yang harus dijalani selama setahun.

4. Menjelang akhir tahun, pegawai akan membuat laporan realisasi capaian SKP atau dengan menyerahkan beberapa dokumen yang telah dikerjakan selama setahun.

5. Pejabat penilai akan melakukan penilaian capaian Sasaran Kerja Pegawai dan menilai perilaku kerja melalui pengamatan terhadap pegawai yang dinilai. Formulir penyusunan sasaran kerja pegawai, penilaian perilaku kerja dan penilaian kinerja dapat disusun melalui sistem penilaian prestasi kerja pegawai kementerian kesehatan.

6. Setelah melaksanakan penilaian sasaran kerja pegawai dan perilaku kerja, pejabat penilai akan menandatangani atau mengesahkan hasil penilaian tersebut. 
7. Selanjutnya hasil penilaian yang telah disahkan pejabat penilai akan diberikan kepada atasan pejabat penilai untuk ditandatangani atau ditetapkan. Hasil penilaian kinerja mulai berlaku sesudah ada tanda tangan dari atasan pejabat penilai. Formulir penilaian kinerja yang telah dibuat akan diberikan secara langsung kepada pegawai yang bersangkutan. Setelah diberikan akan disimpan dalam sebuah folder dan disimpan selama 3 (tiga) tahun.

Pengajuan keberatan atas hasil penilaian dapat dilakukan dengan cara sebagai berikut:

1. Pegawai yang dinilai merasa keberatan atas nilai yang tertuang dalam formulir penilaian kinerja, baik secara keseluruhan maupun sebagian, dapat mengajukan keberatan secara tertulis disertai dengan alasan-alasannya kepada atasan pejabat penilai.

2. Keberatan tersebut dituliskan pada formulir penilaian kinerja pada kolom yang telah disediakan, serta mengembalikan formulir penilaian kepada pejabat penilai paling lama 14 (empat belas) hari terhitung mulai pegawai yang dinilai menerima formulir penilaian kinerja.

3. Keberatan yang diajukan melebihi batas waktu 14 (empat belas) hari tidak dapat dipertimbangkan lagi.

4. Pejabat penilai wajib membuat tanggapan secara tertulis atas keberatan pegawai yang dinilai.

5. Setelah pejabat penilai memberikan tanggapan, wajib menyampaikan kepada atasan pejabat penilai. Serta atasan pejabat penilai wajib memeriksa dengan seksama hasil penilaian kinerja yang disampaikan kepadanya.

6. Atasan pejabat penilai meminta penjelasan kepada pejabat penilai dan pegawai yang dinilai terhadap keberatan yang diajukan.

7. Berdasarkan penjelasan pegawai dan pejabat penilai, atasan pejabat penilai wajib menetapkan hasil penilaian kinerja dan bersifat final serta dapat melakukan perubahan nilai kinerja pegawai.

Metode yang digunakan dalam pelaksanaan penilaian kinerja menggunakan metode rating scale yang dinyatakan dengan sebutan dan angka, sebagai berikut:

Tabel 3. Angka Penilaian Kinerja

\begin{tabular}{|l|l|}
\hline Kriteria & Angka \\
\hline Sangat Baik & $91-$ keatas \\
\hline Baik & $76-90$ \\
\hline Cukup & $61-75$ \\
\hline Kurang & $51-60$ \\
\hline Buruk & $50-$ kebawah \\
\hline
\end{tabular}

Sumber: Bagian Kepegawaian dan Umum Direktorat Jenderal P2P Kementerian Kesehatan

Untuk menentukan angka/kriteria penilaian kinerja tersebut, perlu dihitung rata-rata dari semua unsur penilaian. Berikut ini cara penghitungan untuk unsur sasaran kerja pegawai (SKP) dan perilaku kerja:

1. Perhitungan Sasaran Kerja Pegawai (SKP)

Berikut cara penghitungan aspek penilaian capaian SKP:

$$
\begin{array}{ll}
\text { a. } & \text { Aspek kuantitas }=\frac{\text { Realisasi Output }}{\text { Target Output }} \times 100 \\
\text { b. Aspek kualitas }=\frac{\text { Realisasi Kualitas }}{\text { Target Kualitas }} \times 100 \\
\text { Waktu } \\
\text { c. Aspek } \\
\frac{1.76 \times \text { Target Waktu-Realisasi Waktu }}{\text { Target Waktu }} \times 100
\end{array}
$$

Untuk mengetahui nilai capaian SKP dengan menjumlahkan ketiga aspek tersebut dibagi 3 (tiga) aspek yang ada.

Contoh :

Sasaran Kerja Pegawai (SKP) yang telah disusun ibu Melati Suci Siregar memiliki nilai realisasi output sebesar 65, target output sebesar 65, realisasi kualitas sebesar 80, target kualitas sebesar 100, target waktu dan realisasi waktu selama 12 bulan.

Aspek kuantitas $=\frac{\text { RO }}{\text { TO }} \times 100$

$$
\frac{65}{65} \times 100=100
$$

Aspek Kualitas $=\frac{\mathrm{RK}}{\mathrm{TK}} \times 100$

$$
\begin{aligned}
& \frac{80}{100} \times 100=80 \\
& \text { Aspek Waktu }=\frac{1.76 \times \mathrm{TW}-\mathrm{RW}}{\mathrm{TW}} \times 100 \\
& \frac{1.76 \times 12-12}{12} \times 100=76
\end{aligned}
$$

Jumlah ketiga aspek tersebut $=100+80+76=256$ : $3=85.33$. Maka hasil capaian SKP ibu Melati Suci Siregar yaitu 85.33. Namun untuk mengetahui ratarata nilai capaian SKP perlu menghitung jumlah keseluruhan nilai capaian SKP dibagi jumlah kontrak kerja yang telah disusun.

\section{Perilaku Kerja}

Perhitungan penilaian perilaku kerja dengan cara menjumlahkan seluruh aspek perilaku kerja yaitu orientasi pelayanan, komitmen, integritas, disiplin, kerjasama dan kepemimpinan dibagi 6 (jumlah aspek perilaku kerja).

Contoh:

Ibu Melati Suci Siregar memperoleh penilaian perilaku kerja sebagai berikut:

Orientasi pelayanan: 85

Integritas : 80

Komitmen: 80

Disiplin: 80

Kerjasama: 83

Kepemimpinan: -

Jadi, hasil rata-rata perilaku kerjanya yaitu: $\frac{85+80+80+80+83}{5}=81.6$

Sementara itu untuk mengetahui penilaian kinerja keseluruhan, menggabungkan unsur SKP dan perilaku kerja. Sehingga jumlah rata-rata capaian 
SKP dikalikan $60 \%$ dan hasil rata-rata perilaku kerja dikalikan $40 \%$. Hasil dari rata-rata SKP dan perilaku kerja yang telah dikalikan akan dijumlahkan sehingga akan diketahui jumlah penilaian kinerja pegawai selama setahun. Angka dari penilaian kinerja tersebut dapat menjadi kriteria kinerja pegawai tersebut selama setahun baik atau buruk. Para pejabat penilai atau atasan pejabat penilai saat ini melakukan penilaian kinerja melalui sistem penilaian prestasi kerja pegawai. Sistem tersebut dapat digunakan untuk menilai pegawai, sehingga penilai hanya perlu memasukan nilai capaian SKP dan perilaku pegawai, hasil rata-rata dan kriteria penilaian akan otomatis terhitung.

Adapun penilaian kinerja pegawai telah dilaksanakan pada Bagian Kepegawaian dan Umum Direktorat Jenderal P2P Kementerian Kesehatan, maka penulis menyimpulkan hasil penilaian kinerja pegawai selama setahun sebagai berikut:

\section{Tabel 4. Daftar Rekapitulasi Hasil Penilaian} Kinerja Periode Januari-Desember 2017

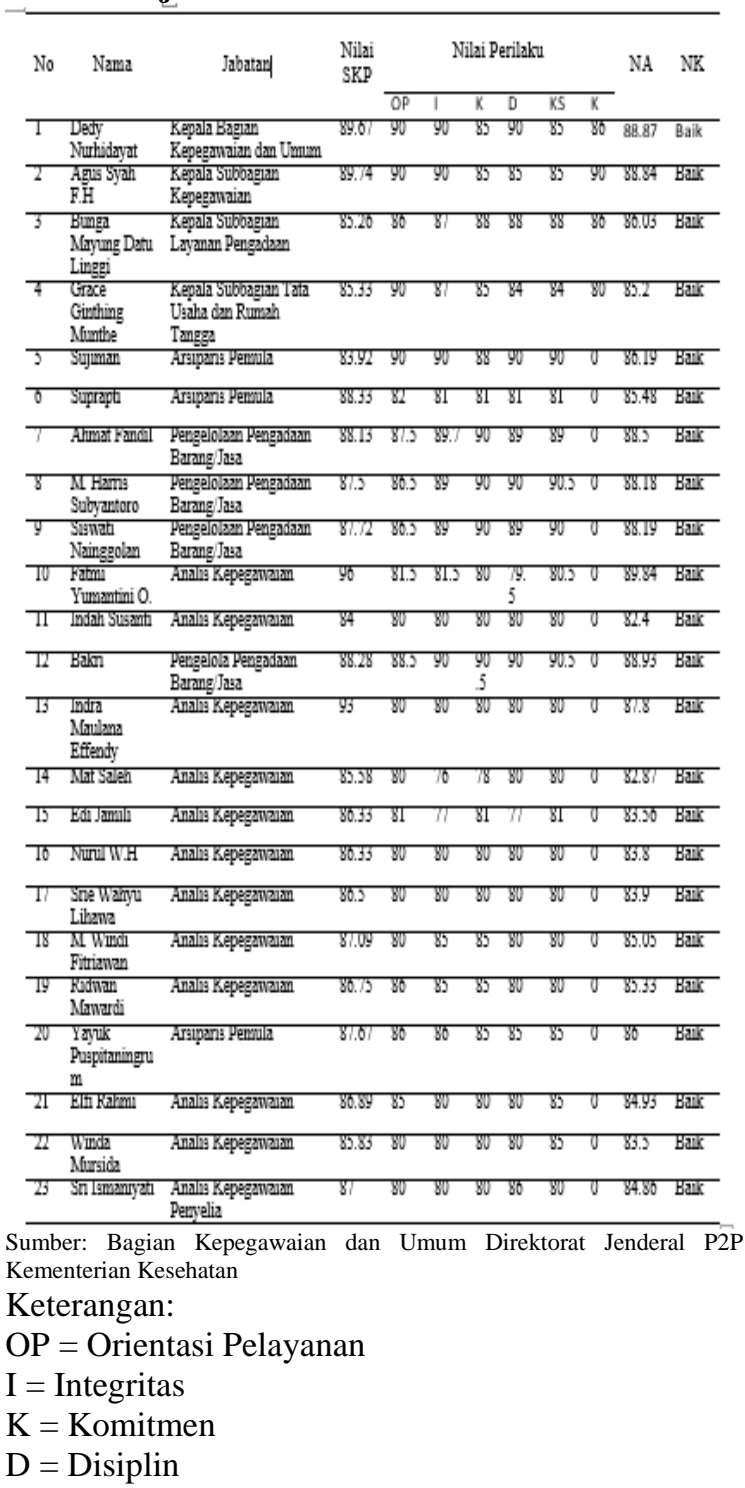

$\mathrm{KS}=$ Kerja Sama

$\mathrm{K}=$ Kepemimpinan

$\mathrm{NA}=$ Nilai Akhir

NK = Nilai Keterangan

Berdasarkan tabel .4., semua pejabat Eselon IV (Kepala Subbagian) maupun pegawai pada Bagian Kepegawaian dan Umum periode 2017 memiliki nilai berkisar 76-90 yang dikategorikan "baik". Pada penilaian capaian SKP semua pegawai memiliki nilai berkisar 76-90 dan termasuk kategori "baik". Nilai capaian SKP yang paling tinggi yaitu 96 dan yang paling rendah 83 . Hal tersebut menunjukkan bahwa baik pegawai, kepala bagian dan sub bagian memiliki tanggung jawab yang baik terhadap tugas yang diberikan oleh atasan. Untuk unsur penilaian perilaku kerja dari ke enam aspek yang ada rata-rata nilai pegawai berkisar antara 76-90 yang masih dikategorikan baik. Nilai perilaku yang paling tinggi yaitu 90 dan yang paling rendah 76, yang berarti para pegawai mampu memenuhi aspek perilaku kerja dengan baik.

Pada unsur kepemimpinan, para kepala bagian atau sub bagian memiliki nilai yang dikategorikan baik, tetapi yang memperoleh nilai kepemimpinan yang paling tinggi yaitu kepala sub bagian kepegawaian dengan nilai 90 hal ini menunjukkan bahwa kepala sub bagian kepegawaian mampu mempengaruhi dan memimpin bawahannya dengan baik serta dapat memotivasi bawahannya. Kepala sub bagian yang memiliki nilai kepemimpinan rendah, antara lain kepala sub bagian tata usaha dengan nilai 80. Salah satu diantara 23 orang pegawai tersebut yang memiliki nilai rata-rata tertinggi dibandingkan dengan pegawai yang lain, antara lain kepala bagian kepegawaian, kepala sub bagian kepegawaian, dan pegawai analis kepegawaian dan pegawai pengelolaan barang/jasa yaitu dengan rata-rata 88.87 , $88.84,89.84$, dan 88.93. Ada salah satu diantara 23 pegawai yang memiliki rata-rata penilaian yang paling rendah, antara lain pegawai analisis kepegawaian dengan nilai 82.4. Walaupun masih dikategorikan "baik", jika diteliti dari semua unsur nilai yang diperoleh masih sangat jauh dibandingkan pegawai yang lain. Maka dari itu, tugas pejabat kepala sub bagian untuk memotivasi dan memberikan pembinaan kepada para pegawainya agar mampu meningkatkan kualitas kinerja agar dapat memperoleh penilaian kinerja yang jauh lebih baik.

Berdasarkan hasil penelitian, terdapat beberapa kendala yang dihadapi dalam pelaksanaan penilaian kinerja pegawai yaitu:

1. Kesulitan yang dihadapi pegawai dalam menyusun SKP. Sehingga terdapat perbedaan antara jabatan dengan tugas atau butir-butir kegiatan yang harus dilakukan.

2. Pejabat penilai masih subjektif dalam menilai bawahannya, sehingga cenderung memberikan 
nilai rata-rata atau ditengah-tengah yang dapat menyebabkan ketidakadilan dalam penilaian.

\section{KESIMPULAN}

Berdasarkan hasil analisa data pembahasan yang telah disusun dalam penulisan laporan penelitian ini, maka peneliti dapat menarik beberapa kesimpulan sebagai berikut:

1. Pelaksanaan penilaian kinerja dilakukan satu tahun sekali, pada periode Januari-Desember. Pada awal tahun pegawai menyusun sasaran kerja pegawai atau SKP dan dinilai pada akhir tahun pada bulan Desember serta penilaian dilakukan oleh pejabat penilai atau atasan pejabat penilai. Unsur yang dinilai terdiri dari penilaian capaian SKP sebesar $60 \%$ dan perilaku kerja yang terdiri dari orientasi pelayanan, integritas, komitmen, disiplin, kerjasama dan kepemimpinan sebesar $40 \%$.

2. Metode pelaksanaan penilaian kinerja menggunakan metode rating scale atau metode yang dinyatakan dengan sebutan dan angka.

3. Rata-rata hasil penilaian kinerja pegawai Bagian Kepegawaian dan Umum pada periode JanuariDesember 2017 mempunyai hasil kinerja yang dapat dikategorikan "baik" dengan rata-rata nilai yang dicapai antara 76-90.

4. Dalam melaksanakan penilaian kinerja terdapat kendala yang dihadapi seperti pegawai mengalami kesulitan dalam menyusun pembuatan SKP dan pejabat penilai masih bersifat subjektif.

\section{REFERENSI}

Ainnisya, R. N., \& Susilowati, I. H. (2018). Pengaruh Penilaian Kinerja Terhadap Motivasi Kerja Karyawan Pada Hotel Cipta Mampang Jakarta Selatan. Widya Cipta - Jurnal Sekretari Dan Manajemen, II(1), 133-140. Retrieved from http://ejournal.bsi.ac.id/ejurnal/index.php/widyac ipta/article/view/2989

Erwin, \& Prabowo, H. (2015). Menggunakan Metode Balanced Scorecard Pada Pt . Bahtera Utama. Binus Business Review, 6(1 Mei 2015), 35-45. Retrieved from http://journal.binus.ac.id/index.php/BBR/article/ view/1438

Januari, I. I., Utami, H. N., \& Ruhana, I. (2015). Pengaruh Penilaian Kinerja Terhadap Kepuasan Kerja dan Prestasi Kerja (Studi pada Karyawan PT. Telekomunikasi Indonesia, Tbk Wilayah Malang). Administrasi Bisnis (JAB), 24(2), 1-8. Retrieved from http://administrasibisnis.studentjournal.ub.ac.id/i ndex.php/jab/article/view/968

Sari, E. P., Setiawan, S., \& Adilah, A. R. (2017).
Analisis Penilaian Kinerja Organisasi Perangkat Daerah Di Kota Bandung ( Studi Kasus Pada Dinas Pemakaman \& Pertamanan; Dinas Kependudukan \& Pencatatan Sipil dan Dinas Pemuda dan Olahraga ) Endah Purnama Sari Santy Setiawan Alif Rifky Adilah Pendahuluan, 9(2), 146-157.

Sinambela, L. P. (2016). Manajemen Sumber Daya Manusia: Membangun Tim Kerja yang Solid untuk Meningkatkan Kinerja (Cetakan 1). Jakarta: Bumi Aksara. Retrieved from http://bacaanindo.blogspot.com/2018/04/manajemen-sumberdaya-manusia-penulis.html

Sutrisno, Edy. (2016). Manajemen Sumber Daya Manusia. Jakarta: Kencana

Peraturan Pemerintah Nomor 46 Tahun 2011 tentang Penilaian Prestasi Kerja Pegawai Negeri Sipil

Peraturan Kepala Badan Kepegawaian Negara Nomor 1 Tahun 2013 tentang Ketentuan Pelaksanaan Peraturan Pemerintah Nomor 46 Tahun 2011 tentang Penilaian Prestasi Kerja Pegawai Negeri Sipil

Tangkuman, K., Tewal, B., \& Trang, I. (2015). Penilaian Kinerja, Reward, Dan Punishment Terhadap Kinerja Karyawan Pada PT Pertamina (Persero) Cabang Pemasaran Suluttenggo, 3(2), 884-895. Retrieved from https://fe.ummetro.ac.id/ejournal/index.php/JS/ar ticle/view/231Penilaian

Zainal, Veithzal Rivai. (2015).Manajemen Sumber Daya Manusia Untuk Perusahaan: Dari Teori ke Praktik. Jakarta: Rajawali Pers

\section{PROFIL PENULIS}

Chusminah SM, SE, MSM, menyelesaikan S1 dari Universitas Gadjah Mada Yogyakarta. Studi S2 Human Capital di Universitas Indonesia Depok. Pernah bekerja di perusahaan manufaktur dan LSM. Sebelumnya aktif sebagai trainer di bidang manajemen dan pengembangan SDM dan mengajar di beberapa lembaga pendidikan dan perguruan tinggi. Saat ini mengajar di ASM BSI Jakarta untuk mata kuliah manajemen SDM, manajemen perkantoran, manajemen kearsipan, manajemen operasi dan produksi, metode penelitian sosial, metode penelitian bisnis dan lainnya. Penulis juga pernah menulis pada tulisan ilmiah dan non ilmiah.

R. Ati Haryati, SH, MH. merampungkan studi S1 dan S2 Hukum di Universitas Jayabaya Jakarta. Selain berkarir di dunia pendidikan di ASM BSI Jakarta, juga menekuni bidang hukum dan terlibat aktif di beberapa organisasi sosial yang berkaitan dengan bidang hukum. Adapun mata kuliah yang diampu antara lain: KNBI dasar, KNBI lanjut, Hukum dan Etika Bisnis. 